\title{
Post-secondary Therapy
}

National Cancer Institute

\section{Source}

National Cancer Institute. Post-secondary Therapy. NCI Thesaurus. Code C158753.

Therapy administered after the second treatment. 